"Financing and financial sustainability of microfinance institutions (MFIs): a conceptual view"

\begin{tabular}{|c|c|}
\hline AUTHORS & $\begin{array}{l}\text { Innocent Bayai } \\
\text { Sylvanus Ikhide }\end{array}$ \\
\hline ARTICLE INFO & $\begin{array}{l}\text { Innocent Bayai and Sylvanus Ikhide (2016). Financing and financial } \\
\text { sustainability of microfinance institutions (MFls): a conceptual view. Banks and } \\
\text { Bank Systems, 11(2), 21-32. doi:10.21511/bbs.11(2).2016.03 }\end{array}$ \\
\hline DOI & http://dx.doi.org/10.21511/bbs.11(2).2016.03 \\
\hline RELEASED ON & Saturday, 02 July 2016 \\
\hline JOURNAL & "Banks and Bank Systems" \\
\hline FOUNDER & LLC "Consulting Publishing Company "Business Perspectives" \\
\hline & \\
\hline NUMBER OF REFERENCES & NUMBER OF FIGURES \\
\hline 0 & 0 \\
\hline
\end{tabular}

(C) The author(s) 2022. This publication is an open access article. 
Innocent Bayai (South Africa), Sylvanus Ikhide (South Africa)

\title{
Financing and financial sustainability of microfinance institutions (MFIs): a conceptual view
}

\begin{abstract}
Recent evidence shows that MFI financing continues to evolve with an increased inclination towards commercial financing. Taking stock on MFI financing and refocusing on the relationship between financing options and financial sustainability (FS) is unavoidable. The authors consummated a literature review based on complementing the little evidence on the subject with both theoretical and implied evidence from related studies in unpacking the relationship. Though donations are losing grip as a popular MFI financing option, review of literature recommends smart subsidies to spur FS and counter inefficiency, mis-targetting, dependency and distortions. As much as debt addresses agency problems and endorses FS, it has to be kept within limits to curb liquidation and mission drift. Deposit attraction augments FS and outreach, though MFIs must prepare to foot licensing costs, otherwise, mission drift ensues. Equity, though scarce in microfinance, is cheap and additive to FS. The authors suggest that MFIs should consider commercial funding, whilst keeping a check on the downside of each commercial financing option to augment FS and multiply outreach.
\end{abstract}

Keywords: financing structure, financial sustainability, microfinance.

JEL Classification: G20, G32.

\section{Introduction}

Widespread failure of MFIs ${ }^{1}$ in Southern Africa Development Community (SADC) prompted recommendations of structuring financial rescue packages for ailing MFIs (Karim et al., 2011). Ironically, the recommendation did not specify the financing structure that ascertains financial sustainability. Questioning the rightful financing structure that can proffer financial sustainability (FS), given the need to ascertain a continued reach out to the poor, is un-avoidable.

Despite the bludgeoning interest in microfinance, research has shied away from addressing the relationship between financing and FS, as few studies delved on the subject. With the intent of informing the structuring of MFI financing, hence, pledging a permanent existence of MFIs (FS) and a salient outreach to the poor, we consolidate theory and empirical evidence on MFI financing and FS. The realization is that financing of MFIs continues to evolve with an increased inclination towards commercial financing (Johnson, 2015; Cull et al., 2011). Noting the limited evidence on the subject, most of which is implied, we sought to fuse the theory and evidence on the relationship between financing and FS. But how do we accomplish this mission?

We resort to the review of literature, allowing us to explore the various financing options that MFIs are capable of using, the probable merits and costs of the same, as well as their implications on FS. We relied on

(C) Innocent Bayai, Sylvanus Ikhide, 2016

Innocent Bayai, Ph.D. Student, University of Stellenbosch Business School, South Africa.

Sylvanus Ikhide, Development Finance Professor, University of Stellenbosch Business School, South Africa.

1 Specialized financial institutions providing capital and financial services to the poor and small enterprises in developing countries Dominice (2012). the few studies which, specifically addressed MFI financing and FS and complemented such with implied evidence which in part, answered our concerns. Assuming this methodology, we were able to survey the relationship between MFI financing and FS, as well as draw MFI financing lessons thereof. The intuition is to trigger more scholarly examination, as this research area has remained undeveloped.

The paper proceeds by manner of providing a detailed explanation of FS in Section 1, whilst financing of microfinance, as well as the trade-off between MFI financing and FS is covered in Sections 2 and 3. The final section wraps up the study by providing conclusions and recommendations.

\section{Financial sustainability (FS)}

Intensive efforts to fight poverty saw the emergence of microfinance (Kimando et al., 2012; Brau \& Woller, 2004). The provision of financial services to the poor is hinged on the assumption that MFIs exist eternally to solve social ills such as poverty, unemployment and low living standards (Iezza \& La Cour, 2010; Khawari, 2004; Bogan, 2012). Nyamsogoro (2010) stated that having no MFIs is better than having unsustainable ones. FS, thus, fortifies an uninterrupted delivery of financial services (Von Pischke, 1996).

Massive applauding of FS as additive to efficiency and pronounced outreach (Brau \& Woller, 2004) has ignited an FS drive in microfinance (Hallway et al., 2011). However, MFIs, unlike traditional financial institutions, pursue the double bottom lines, i.e., the social and the financial obligation (Mersland \& Strom, 2010; Kumar, 2012). Therefore, FS is uniquely defined, since it is not an end in itself (Rhyne, 1998), but meant to further the social aspect too. So, what is FS? 
Khandker (1996) notes that FS defines the ability of an MFI to continue operations owing to viability of operations, hence ability to cover operational, financial and adminstrative costs. Referring to the Grameen Bank, Khandker notes that the bank attains FS, if the cost per unit of capital lend is matched with the interest charged per unit to clients. FS, thus, can only be attained where interest charged per unit of principal on loans exceeds the associated costs of raising the principal.

Intuitively, an MFI is viable if revenue exceeds the operational cost per unit of principal lent. Losses occur once lending rates fall below the operational cost, thus, MFIs would require subsidies to bail them out (Guntz, 2011). Critical aspects of FS include disbursement and recovery of loans. This is because loan sizes inform the cost of lending per unit of principal loaned out. Loan recovery determines the default rate and the cost of default, whilst the lending method determines the recovery and administration costs (Khandker, 1996).

FS, since it is a term that has been widely adopted by different sectors, tends to have variant meanings too. The Association of Local Governments in Australia denotes FS as the ".....ability to manage its finances so that it can meet its spending commitments, both now and in the future. It ensures that future generations of taxpayers do not face an unmanageable bill for government services provided to the current generation". (LGA, 2015, p. 3). FS, therefore, "....maintain or expand services within the organization, while developing resilience to occasional economic shocks in the short term" (Sontag-Pedilla et al., 2012). Zviniene \& Whitehouse (2010) writing on behalf of the World Bank stressed out that FS for all revenue-based programs is bend on making sure that all costs are covered and excesses are realized that can push the program into the future. So, is FS different from profitability?

Kipesha \& Xianzhi (2013) citing CGAP (2004) acknowledge that sustainability is a pace towards profitability. However, Rosenburg (2009) equates FS to profitability. Both are responsive to cost reduction, i.e., administration, transaction and operating costs on the back of revenue generation and innovative funding methodologies. Sustainability has three notches, the first one being operational sustainability ${ }^{2}$ followed by FS. Profitability is a supreme sustainability measure where cost of capital, inflation cost and all non-cash items on top of operating expenses are paid out of operating revenues only. Surpluses realized by a profitable MFI are used to expand outreach (Rosenburg, 2009; Ayayi \& Sene, 2010; Tehulu, 2013).

The FS movement sparked a debate on mission drift (Roy, 2010; Hermes \& Lensick, 2011), brewing a storm popularized as the microfinance schism (Morduch, 2000). Confirmation of microfinance schism is unconvincing, especially the effect of FS on the depth of outreach (see Hermes \& Lensick, 2011; Hermes \& Lensick, 2007; Amin et al., 2003; Hoque \& Chisty, 2011; Quayes, 2012; Paul, 2010). Despite the contentous evidence, FS has remained a requirement for MFIs, given the faltering record of donations, grants and subsidies in financing development (Johnson, 2015; Millson, 2013).

Financially sustainable MFIs are on record for capitalizing on scales, exercising cost conscious, promoting innovation, reduce administrative and information asymmetry costs, lower adverse selection and moral hazard, hence, advance outreach,whilst suffering least losses (Quayes, 2012; Paul, 2010; Hoque \& Chisty, 2011). Seeking FS has led governments to privatize subsidizied, inefficient and loss-making credit programs and parastatals (Robinson, 2001). Likewise, MFIs are moving from donor financing to commercial financing (Forkusam, 2014). Shifting from the old paradigm (concessionary funding) to a new paradigm (commercial funding) concretizes cost-efficiency in microfinance. The old paradigm is pro the social mission, whilst the new paradigm backs FS. Robinson (2001) claims that the new paradigm has created accountability, transparency, efficiency, economic interest rate setting, capital mobilization and appropriate management remuneration. But, how is FS measured?

1.1. FS measurement. The Operational Self Sufficiency (OSS) measure for FS is popular and has been used in innumerable recent studies (see Sekabira, 2013; Bogan, 2012; Quayes, 2012; and Kipesha \& Xianzhi, 2013). OSS measures how adequate MFI revenues are to cover the total costs (operating costs, loan loss provisions and financial costs) disregarding all grants, subsidies and donations. OSS, a Microfinance Information Exchange (MIX) framework, is expressed as follows:

$$
O S S=\frac{\text { Total Operating Revenue }}{\text { Financial expenses }+ \text { operational costs }+ \text { loss on loan expenses }},
$$

\footnotetext{
${ }^{2}$ MFI is able to cover operational costs irrespective of the source of cashflows.
} 
where: OSS < 100\% = unsustainable; $100 \%<$ OSS < $110 \%=$ operationally sustainable, and OSS $>110 \%=$ $=$ financial sustainability.

Operating revenue includes interest income from both current and past loans, interest from re-structured loans, interest from all investments, fares, service charges, as well as penalties from late settlement of loans ${ }^{3}$. Expenses include financial, operating and loan loss expenses (Cull et al., 2009). Financial unsustainability means an MFI cannot meet its operating costs, thus, is bound to fail unlessit gets financial aid. An
OSS in excess of $100 \%$ defines an MFI's ability to meet its operating costs. Besides operational costs, an MFI has to meet financial costs of financing resources it uses. An OSS of at least $110 \%$ defines an MFI's knack to meet both operating and financial costs (Bogan, 2012).

Rosenberg (2009) provided an FS measure (Financial Self-Sufficiency - FSS) for MFIs which receive donations, grants and subsidies (NGOs). The FSS measure is expressed as follows:

$$
F S S=\frac{\text { Revenue }(\text { Excluding grants \& Extra }- \text { ordinary items })}{\text { Total Expenses }+C F A+I S A+I A},
$$

where: CFA - subsidized cost of funds adjustment; ISA - in kind subsidy adjustment, and IA - inflation adjustment.

An FSS measure of at least $100 \%$ implies financial sustainability, whilst anything below $100 \%$ is regarded as un-sustainability. FSS is a subsidy-adjusted measure of FS popular with NGOs (Manos \& Yaron, 2007). Revenues are adjusted to cater for soft loans, in-kind donations and inflation adjustment. The subsidy dependence index (SDI), though touted as the best FS measure, is least used owing to lack of data to estimate it (Rosenburg, 2009). SDI measures the margin by which an MFI has to hike its interest rates for it to cover all costs including adjustments.

1.2. Trends and factors explaining FS. It has become apparent that serving the poor can be pursued concurrently with the need to attain FS. The blended value theory, though unpopular in microfinance states that "....social, financial and environmental are integrated and inseparable, and, when intending to create one type of value, other types of value are inescapably produced simultaneously" (Vacklen, 2010). Intutitively, FS comes in to bolster the social mission by adopting a commercial scope in microfinance. Blended value in microfinance has allowed social and commercial oriented investors deriving different 'values' from microfinance to invest in one MFI. A single MFI thus can accommodate 'impact-first blended value investing' and 'profit-first blended value investing' though at different degrees.

Mersland \& Strom (2012) asked "...are innovations needed to reach out to the poor people and small businesses?" Microfinance, a financial innovation in itself (de Aghion \& Morduch, 2005), has ushered further innovation in the name of sustainable finance. Noting that subsidized microfinance failed (Vacklen, 2010), sustainable finance ascertain perpetual financing of the poor on the basis of "the poor can pay

\footnotetext{
3 No subsidies, grants or donations are included in the operating revenue.
}

back" and "provision of microfinance can be done in a financially sustainable manner". Innovation eddifies FS given viability in serving the poor and women clients, NGO profit orientation, commercialization and use of technology in cutting costs (Mersland \& Strom, 2012; Jaramillo, 2013). The World Economic Forum (2012) notes that no time shall it be possible to declare that financial innovation is complete as long as new opportunities, problems and market imperfections are visible. FS presents itself as an innovation meant to ascertain self-sufficient MFIs capable of serving financial needs of the marginalized.

Sustainable finance has also been aided by the financial infrastructure. Duflos et al. (2013) noted that financial infrastructure “...includes accounting and auditing standards, credit reporting systems (credit registries and bureaus), collateral and insolvency regimes, and payment and settlement system". Financial infrastructure curbs information asymmetry, reduce risk to creditors through clear legal provisions, hence, increase the supply of funds to MFIs. IFC (2010) presses that standardized accounting and auditing promotes financial perfomance based lending and lowers loaning costs. As MFIs adopt these standards, they attract "funding beyond donors and government subsidies" (Asian Development Bank, 2000). Regulation and supervision has allowed MFIs to collect deposits too as "market based microfinance" took to the fore allowing for the integration of MFIs into the mainstream financial sector. FS is thus based on cost cutting technology, novel business models and credit scoring, restrained adverse selection and moral hazard assuring further injection of commercial capital and expansion of operations (IFC, 2010).

\section{Financing of microfinance}

Kapper (2007) estimated that $80 \%$ of the world's population is financially excluded, thus demand for microfinance is high. Paul (2010) wrote that "Demand for microfinance currently outstrips supply by $\$ 300$ billion and, in order to reach those without access, MFIs need to expand". Capital constraints 
and high operating costs in developing countries limit access to financial services by the poor (Kumar, 2012). High prevalence of financial exclusion is caused by the lack of strong financial intermediation backed by sound financing (Kapper, 2007). The financing options assumed by MFIs, in part, determine the financial services they can provide, and the associated cost.

Hoque \& Chisty, (2011) noted the marked transition of NGOs and non-bank MFIs into regulated microfinance banks as the search for adequate financing sours. de Sousa-Shields \& Frankiewicz (2004) wrote that "the microfinance sector, in most countries, has proven its commercial viability and that MFIs can serve the market profitabily when applying best practise asset management". Given that donors and governments are weaning off MFIs, new innovative financing methods are being instituted (Hoque \& Chisty, 2011). They wrote that "...commercialization is the only way to attract money needed to expand the outreach and to liberate the system from dependency on foundations and other charitable donors". However, the debate on the proper funding of microfinance which ascertains extended outreach and the long-standing of MFIs remains open.

2.1. Financing sources. Financing structure of MFIs mimics that of commercial banks (Karim et al., 2011). Profit-motivated MFIs employ debt, equity and savings whilst grants, subsidies and donations are used by NGOs. Debt is mainly supplied by private investors (non-commercial), commercial banks and multilateral organizations. Equity is owned by national and international nonprofit institutions and development banks. Estimating how microfinance is financed throughout the world, CGAP, (2004) attributed 25\%-35\% of MFIs to deposit/savings financing. A further 35\%-40\% are debt financed with 30\%-40\% being equity financed. Hermes \& Lensink, (2011) underscored that commercialization of microfinance, competition, technology, financial liberalization and regulation explain the change in financing structure of MFIs.

MFIs can get grants from governments and foreign donors in the form of low interest loans, as well as microcredit loan initiatives (Buss, 1999). Humanitarian donors bankroll MFIs, though on a revolving fund basis (Kapper, 2007). Corporate social responsibility activities give to NGOs, which, in turn, finance MFIs or can operate an entity which does the lending business. Governments can issue concensionary loans to MFIs and may own debt and equity or provide grants to MFIs. MFIs progovernment development goals, especially poverty reduction get the funding. Alternatively, governments may fund their own MFIs. Governments of developed countries invest in microfinance through Microfinance Investment Vehicles (MIVs). MIVs provide capital to MFIs by investing in microfinance on commercial basis (Isern \& Porteous, 2005). They act as conduits of both public and private capital meant for microfinance programes. Popular MIV investors include public funds such as International Finance Institutions (IFIs), institutional investors (pension funds), as well as foundations bent on social values, NGOs and philathropic individuals. Prominant IFIs include International Finance Corporation (IFC); European Bank for Reconstruction and Development (EBRD), Kreditaustalt fur Weideranfban (KfW) and the USAID (Kapper, 2007; Isern \& Porteous, 2005). These sources formulate cheap financing for MFIs.

Other commercial funding sources include commercial banks. Banks regard MFIs as their clients, thus, they churn out loans to MFIs. Indirectly, commercial banks may assume an investor's role by holding equity in an MFI. Reacting to competition and the need to up revenues, commercial banks down-size - extending their business operations by out-sourcing retail of microfinance products and services through established MFIs (Isern \& Porteous, 2005). Other MFIs have turned public to raise capital. Compartamos went public in 2007, whilst SKS Microfinance managed to raise $\$ 358$ million after going public (Hoque \& Chisty, 2011). This has marked a transition in the thinking behind funding of microfinance as it has become apparent that MFIs can source financing in competetive markets just like any other corporate. MFIs can also attract deposits and use such deposits to fund outreach only upon meeting regulatory requirements. Deposits are considered stable and can fund MFIs over a long period of time, thus, MFIs can attain solid growth (Kapper, 2007). However, use of deposits is subject to the regulations prevailing in the host country.

Rhyne, (1998) reiterates that the 'sustainability camp' view private sector financing as the future of microfinance though the "poverty camp" value donor financing (Brau \& Woller, 2004). The poverty camp believes that donations are poororiented and fear that profit oriented MFIs initiate mission drift as they stir clear of high administration costs associated with small loans designed for the poor. The sustainability camp posits that donations threaten outreach in the future as there is no assurance of continued capital injection by donors (Ayayi \& Sene, 2010). Also, governments and donors have failed to fund microfinance at a mega-scale hence the un-accomplished goal of fully serving the poor. Since the private sector has unlimited resources, it can ascertain un-interupted and indefinite financing of the poor. The idea of commercialisation has seen 
deposit attraction plus debt usage balloning evidencing the evolution of MFI financing (de Sousa-Shields \& Frankiewicz 2004).

2.2. Microfinance financing theories. Whilst the Modigliani and Miller (M\&M) capital structure theory is popular in corporate finance, its relevance, given the unique nature of microfinance is unfound. The traditional firm assumed by the M\&M theory is at variance with lending institutions which are capable of attracting deposits, thus the theory requires adjustments for it to suit lending institutions guided by the double bottom line ${ }^{4}$ (Cohen, 2003). We present three appropriate theories hereunder, i.e., the agency theory, the life cycle theory and the profit incentive theory.

2.2.1. Agency theory. One relevant theory is the agency theory. It hints on the role of debt in aligning management's performance to that of the owners. Kar, (2012) confirmed that debt usage by MFIs increases profitability measures and improves cost efficiency. The theory asserts that higher leverage is a useful governance mechanism which helps to reduce wasteful cash flow by a threat of liquidation (Williams, 1987). This may also lead to increased pressure on management's part to generate enough cash flows to service debt obligations. However, agency costs of monitoring management activities lessen the gains. Agency costs may be large in the microfinance industry as MFIs are, by their nature, informationally opaque (Hudon \& Traca, 2011).

2.2.2. Life cycle theory (LCT). Fehr \& Hishigsuren, (2006) posited that capital structure of MFIs changes with the LCT phases of an MFI. Conditions set by capital providers do not allow MFIs to have much choice, thus, certain MFI growth phases are reminscent of a specific financing structure. The related cost of capital may limit MFIs' funding choices. Hoque \& Chishty, (2011) concurred by writing that the LCT explains the financing of MFIs as they evolve into financially sustainable institutions. Though Hoque \& Chishty, (2011) identified three MFI, growth stages the notable phases, as outlined by Kapper, (2007) are: the start-up, expansion, consolidation and the integration stage.

In the start-up phase, MFIs are financed through donations and concessionary funds. This is because it is too risky for private investors (equity). Since donors want to control the lending, having equity in the MFI would allow them to achieve that. Setting up systems and blunt business models at the start-up phase constrain. NGOs are most successful in this

\footnotetext{
${ }^{4}$ The social mission (serving the poor) and the financial mission (being financially sustainable).
}

phase because of the subsidies and grants they receive. The expansion phase emphasizes on the extension of operations once operational challenges in the prior phase are solved. A good business model expands MFI operations and outreach. The expansion stage introduces equity by NGOs and public investors to attain MFI stability. International Finance Institutions (IFIs) come in to provide seed capital. IFIs' capital comes in-between donor funds and commercial funding. However, subsidies are still available for MFIs, that is soft loans and grants (Brau \& Woller, 2004).

The consolidation stage commercializes the operations of an MFI. MFIs invest in acquiring sustainability by formalizing operations through observing regulation which allow for the attraction of deposits. Deposits expand loaning, but at low cost. The consolidation phase has an introduction of commercial debt in the funding structure. The stability attained allows funds to be acquired from banks (domestic). Foreign funds are used as guarantees for debt acquired by MFIs in the local market. More private capital can now be sourced. However, only large MFIs afford such funding because they are of low risk, thus can attract private investors who are keen on returns. Domestic debt is, now the prime source of financing, as foreign debt has connotations of exchange rate risk and capital flow regulations making it costly. Commercial banks involved in microfinance do not go through this transition process, though NGOs are most likely to proceed this way (Kapper, 2007).

In the integration phase, MFIs enter mainstream financial sector by turning into microfinance banks. Subsidies and grants are no longer part of the financing structure of MFIs, and most MFIs are financially sustainable and profitable. The integration stage is synonymous with high outreach. However, there is a belief that, as MFIs acquire financial sustainability, they may neglect the core poor (Morduch \& Haley, 2002; Morduch, 2000). Pro sustainability advocates such as Rhyne, (1998) posit that, as the MFI develops, so are its clients, thus, at integration stage, the loans granted to clients wont be small anymore. Effectively, there won't be any mission drift with regards the size of the loans. Notable, however, is that more clients get served by sustainable MFIs.

Despite the popularity of the LCT, evidence on it remains scanty, as little work has been done on it. In an effort to answer the question: do MFIs develop towards financial sustainability, Bogan, (2012) used cross sectional data of the top 300 MFIs. Results did not support the LCT, but underscored the importance of capital in determining FS. This is 
because capital constraints and costs limit the expansion of microfinance. De Sousa-Shields \& Frankiewicz, (2004) noted that the shift to private capital has already begun, and some MFIs are being found fully funded by private capital. The authors emphasized that the ability of an MFI to survive any stage of the LCT is a function of the ability to attract the ideal financing resources.

However, Fehr \& Hishigsuren, (2006) note that whilst market - oriented financing for MFIs is noticeable, there is still evidence of non-commercial financing which oposses the LCT evolution style. Financing programs (e.g., ACCION) linking MFIs with investors and commercial banks through credit enhancement lower financing costs for MFIs as they turn into commercially viable entities, thus, defying the LCT.

2.2.3. The profit incentive theory (PIT). The PIT states that use of commercial funding sources at any stage of MFI evolution enables MFIs to meet the microfinance promise (Bogan, 2012). The usage of commercial funding raises cost conciousness, efficiency and outreach. In concurrance with the institutionalist paradigm, the PIT seconds that donor funding is limited in amount, thus, cannot fund microfinance at a mega-scale given the increasing demand of microfinance.

The theory upholds that MFIs pursuing profits thrive to maximize revenue, whilst minimizing operational costs, so as to cover expenses and build surpluses. MFIs funded by grants and subsidies do not respond to profit maximization and cost minimization pressures, thus, opt for outreach depth over efficiency by serving the poorest and rural clients which have extra lending costs (Bogan, 2012; de Aghion \& Morduch, 2005).

Evidence of the PIT, as put across by Bogan, (2012), notes the increasing international and internal pressure on MFIs to shed-off subsidies and grant financing. Institutions such as ACCION International has made frontic efforts to link MFIs with equity financiers, debt financing, as well as other commercial funding sources. This has availed an avenue for MFIs to seek independence from grants and subsidies.

2.2.4. Other financing determinants. Amongst other key determinants of the financing structure of MFIs, Fehr \& Hishigsuren, (2006) noted that regulatory provisions play a critical role. They wrote that "...national and regional variations in financing patterns are subject to regulation..." Regulated MFIs are normally allowed to attract deposits, thus, are set to benefit from low cost savings (Fehr \& Hishigsuren, 2006). Thus, in countries where regulation outlaws deposit collection, MFIs tend to consider more debt and equity financing, compared to countries that allow attraction of savings. The incredible trend of surging deposits in Africa is attributable to several African countries passing laws that de-criminalize deposit collection (Lafourcade et al., 2006).

Whilst deposits can be a source of cheap financing, regulation and supervision present a cost to MFIs. Cull et al., (2011) showed that regulation negatively affects outreach same as women borrowers. Regulation, thus, poses additional cost to MFIs which may force them to cut on smaller loans meant for the poor and women clients and issue out more lumpier loans. Costs associated with deposit attraction include minimum capital requirements, legal representation and the hiring of experts in effecting payment systems, as well as qualified accounting personel who can do reporting as per regulatory requirements.

Microfinance funding trends are also subject to localized characteristics that have a bearing on the development of institutions (Bogan, 2012). These characteristics include historical legacies of both saving and lending, as well as legal provisions defining the operations and the raising of capital. This explains why Latin America has lots of regulated MFIs compared to Middle East, North Africa, Eastern Europe and Central Asia. Also, various microfinance charters mean different players with diferent missions, hence the difference in the funding and funding patterns and transitions.

\section{Relationship between financing and FS}

Studies specifically addressing MFI financing and FS remain few, hence, some evidence presented hereunder is implied in studies covering implications of determinants of FS or the relationship between FS and outreach. Of note is that evidence is contentious, as outcomes from different studies give conflicting results. This validates claims by Cull et al. (2009, p. 19) that microfinance trade-offs vary with regions, hence, evidence has to be evaluated noting regional characteristics. However, a generalized perspective is assumed in this paper.

3.1. Subsidies and FS. Abdelkarim, (2002) wrote that it has dawned to most NGOs that donations allocated to them fall short of the expansion needs of microfinance. Louis \& Bartm, (2013) concurred by stating that "shunning external funding and focusing on generating sufficient income from their operations MFIs enjoy efficiency and can survive into the future". Amin et al., (2003) reflected on the same by writing that subsidies have a "baffling record of political manipulation" and diversion from poor clients. Murdoch, (1999) affirmed that "If donors tire of funding the bill for microfinance, achieving financial sustainability and increasing returns to equity is the only game to play". His assertion is based on donors' 
budgets being limited, thus, restricting both FS and outreach prospects.

Though FS negates the usage of donations in financing microfinance (Sekabira, 2013), donations are on record for supporting new microfinance programs giving them "breathing space", whilst upgrading systems and human resources needs. This amplifies FS in the long run. Given limited financing sources in initial stages, donations remain a dependable financing source for MFIs in their quest for FS (Hudon \& Traca, 2011). Aveh et al., (2013) noted that Subsidy Dependency Index (SDI) is still high, implying that most MFIs are subsidized. Kinde, (2012) showed that donations amplify FS up to a certain level, beyond that level, donations start to undo sustainability. The findings are in line with Hudon \& Traca, (2011) who wrote that there is a positive relationship between subsidy intensity and FS with a threshold limit on the subsidy. Effectively, subsidies do not have a negative effect on FS as long as they are within limits, i.e., "smart subsidies". So, what are smart subsidies? And how can they support financial sustainability?

De Aghion \& Morduch, (2005) defined smart subsidies as "...carefully designed interventions that seek to minimize distortions, mistargeting, and inefficiencies while maximizing social benefits". Brau \& Woller, (2004) established that subsidies are efficient if used to finance innovation and establishment costs for MFIs. Once operations are viable, donations are relegated out of the financing structure of MFIs. This explains the trend by donor organizations and governments to embrace sustainability-based reporting by NGOs (Rosenburg, 2009). Morduch, (2005) noted that smart subsidies can open new MFI financing, expand outreach and reach the poor better, though it is still undeniable that poor structuring and improper targeting propagate distortions and fosters dependency, limit FS and outreach. Morduch extended his writings stres-sing out that transparency of subsidies has to be instituted same as setting rules and timeframes for withdrawal of subsidies.

De Aghion \& Morduch, (2005) identified three ways of making subsidies smart, namely, "subsidize the program, not the customer", "strategic short-term subsidization of very poor clients" and "strategic subsidization over long periods". These are presented hereunder.

\subsubsection{Subsidize the program, not the client.}

- MFIs charge interest rates that cover all their costs and still provide for a profit margin. This explains the usurious interest rates which MFIs might have to charge clients if they are to be sustainable. By subsidizing the program, MFIs can charge clients market interest rates (these are lower than rates that can make an MFI sustainable), and a subsidy would cover the shortfall. Effectively, lower interest rates are charged to clients, whilst the shortfall required to make the institution sustainable is subsidized as the MFI grows its scales to levels which enable it to be sustainable at market interest charges (Morduch, 2005).

- Subsidizing the program and not the client include supporting start-up programs. If operational costs are high in the early days with the average costs going down across time as scales improve, subsidies can be used only during initial stages and are stopped when costs can now be covered by interest charged to clients.

- Since record has it that donors find it sticky to pull the plug on donations, recommendation from de Aghion \& Morduch (2005) pins MFIs to attain efficiency at given timeframes in preparation for withdrawal of subsidies. Strict perfomance measures have to be adhered to. Donors might also consider funding research and innovation which can be used by MFIs in capacitating them rather than directing subsidies to the MFIs.

\subsubsection{Strategic short-term subsidization of very poor} clients.

- Very poor clients lacking business acumenship are trained so that they are able to utilize funds borrowed from MFIs in a business sense making lending to the poor sustainable. Such clients may access loans below the market rate for a specified period to allow them to put together their businesses. The Income Generation for Vulnerable Group Development (IGVGD) done by BRAC in Bangladesh falls in this category. The structuring of the program include food subsidies stretching for 18 months and 6 months of training meant to move the poor out of poverty extremes. After saving for the entire training period building a capital base, trainees enter the main BRAC programs at par with other existing customers, i.e., they borrow at the market rate. Subsidies, thus, are meant for vulnerable clients, hence, an MFI can get subsidies for as long as it is meant to capacitate the core poor. Once the clients are on their feet, subsidies are stopped. Subsidies are, thus, used to fund initiation of a relationship which ends up sustainable (Morduch, 2005).

\subsubsection{Strategic subsidization over the long term.}

- Small loans, though meant for the poor, are costly to MFIs in terms of servicing and administration compared to bigger loans. Thus, MFIs are forced to hike lending rates on small loans, thereby causing mission drift. Smart subsidies are thus used to cover the extra cost MFIs incur in dishing out small loans. Such subsidies would stop once clients graduate into big loans whose related cost is lower than that for small loans. 
Deductively, all clients, whether their loan is small or big, are charged the same rate though on the background, subsidies make up for the extra cost on small loans.

Morduch, (2005) added that smart subsidies can be used to "crowd in" other commercial financing options. Securitization involving SHARE Microfin Ltd and ICICI Bank in India was able to go through after an $8 \%$ first-loss guarantee was provided by the Grameen Foundation as a subsidy. The subsidy, thus, "crowded-in" new financing worth $\$ 4.3$ million. Such guarantees are essential where donors signal their approval of an MFI's efficiency and prospects. In that realm, other sources of financing are enticed to inject their money in microfinance. But are donors equiped to know the extend of smart subsidies required by MFIs?

In relation to smart subsidies, Morduch, (2005, p. 16) notes that "...at present, there is almost no careful evaluation, and it is time to shift the balance". Thus, wherever subsidies are used, there must be a standard way of "demonstrating social impacts, those impacts should be measured using rigorous statistical analyses, with solid control and treatment groups and attention to measuring causal relationships". CGAP, (2005) recommended that donors must review an MFI's pledge to attain operational efficiency and financial sustainability within the shortest time possible. Perfomance indicators such as operational efficiency, interest rate and fees policy, as well as reporting standards must be used to gauge management's prowessness.

3.2. Debt versus FS. The agency theory approves the use of debt in limiting agency costs and spur profitability (Kumar, 2012). Coleman, (2007) confirmed the agency theory noting that highly leveraged MFIs are able to address risk, reduce moral hazard and adverse selection, as well as reaching out to more clients. The threat for liquidation and loss of personal benefits propell managers to improve efficiency. Hoque \& Chishty, (2011) studied how commercilization of MFIs affected MFI financing structure, FS and mission drift. Panel methods adjusted for random and fixed effects revealed that debt usage reduces outreach depth, though it upholds FS. Abor, (2005) confirmed the same results noting that highly leveraged MFIs achieved efficiency (FS) and enjoyed economies of scale. Restraining adminstration costs associated with small loans as MFIs pursue FS usually leads to mission drift under debt financing (Brau \& Woller, 2004).

On the contrary, Sekabira, (2013) and Tehulu, (2013) noted the limitation debt has on FS given availability of cheap equity in Uganda and East Africa respectively. The study acknowledges portfolio at risk, man- agement inefficiency, loan size and intensity as key determinants of FS (Tehulu, 2013). Kinde, (2012) focused on FS of Ethiopian MFIs and showed that capital structure had an insignificant effect on FS. Debt recorded an insignificant negative impact on FS mainly because of the cost associated with debt financing. This is supported by Kiiru, (2008) who noted significant negative association between debt and FS in Kenya. But can FS explain the level of debt assumed by MFIs?

Kumar, (2012) identified reverse causality flowing from FS to MFI debt levels. The efficiency-risk hypothesis states that, efficient MFIs employ high debt ratios compared to other MFIs because high efficiency cuts the anticipated costs of financial distress and bankruptcy. High profit efficiency substitutes to some extent, for equity capital in insulating the firm from future crises. Conversely, the franchise-value hypothesis explains low debt levels in highly efficient MFIs keen to lock-inprofits, hence, reduce liquidation chances (Margaritis \& Psillak, 2009). Faulkender \& Peterson, (2004) demonstrated that MFIs have different leverage ratios owing to whether they have access to public bond markets or not. The realization was that MFIs which raise debt from public markets have 35\% more debt.

Though debt raises cost-efficiency for MFIs, care must be taken not to over-use it as it invites high service fees which, in turn, spark bankruptcy and nullify FS efforts (Kiiru, 2008). MIX, (2013) notes the low uptake of debt by MFIs across the world. Kiiru, (2008) also notes the decreasing role of debt in MFI financing in Kenya as it dents profitability. The understanding is that MFIs tie themselves to debt for as long as they are not able to collect deposits. It is, however, vital to note that, for new MFIs, debt is less costly compared to deposits. All the same, deposits cannot fully service loan demand, hence, debt covers the shortfall for MFIs that opt to remain non-deposit taking (de Sousa Shields \& Frankiewciz, 2004). The duo notes that most debt capital is denominated in hard currency (Euro or the USD) which translates into currency risk given turbulence in the foreign exchange market which MFIs are not prepared to tackle. This might further derange efforts towards FS (CGAP, 2004). They note that, "As MFIs take on more sophisticated debt instruments, increasingly sophisticated and informed treasury financing skills are required to determine the cost and liquidity advantages of different tenors and types of debt, including savings. Efficient liability management and planning is key, as growing institutions need to ensure sufficient liquidity while maintaining a minimum of non-performing assets. Striking this balance demands strong liability information and analytical tools". 
3.3. Deposits and FS. Deposits have become a key MFI financing option world-wide except for the MENA region (MIX, 2013) with special mention of Africa where deposits surpass the volume of loans (Lafourcade et al., 2006). Kinde, (2012) indicated that it is through savings that MFIs can expand loan portifolios, improve on sustainability, reduce loaning rates and move towards satisfying demand. Though, Tehulu, (2013) finds an insignificant influence of deposits on FS in East Africa, Khandker, (1996) perceives that savings mobilization indicates an MFI's ability to self-finance, hence, attain independence and permanency (Khawari, 2004). Iezza \& La Cour, (2010) and Kiiru, (2008) noted that deposit attraction has a marked contribution to FS, hence, it has become the preferred MFI financing option. Deposits are attracted at a low cost and are used to churn-out loans allowing MFIs to enjoy salient profit margins from the interest rate differential. This lessens pricey borrowing for on-lending by MFIs (Kiiru, 2008; de SousaShields \& Frankiewicz, 2004).

However, Cull et al., (2008) notes that many countries outlaw deposit collection unless where regulatory requirements are observed. Being regulated poses a cost to MFIs especially upgrading information systems, aligning with capital requirements and the hiring of experts (CGAP, 2005; Tehulu, 2013; Cull et al., 2009). De Soussa-Shields \& Frankiewicz, (2004, p. 38) figured out that "Many MFIs are, basically, credit management companies with both human and physical resource assets tied closely to credit management and growth. Changing focus from credit to savings has proven challenging and, in many cases, collecting significant deposits has taken longer than many MFIs would have thought necessary". Licensing costs, thus, may push MFIs to grant bigger loans and limit loans to women borrowers (mission drift) (Cull et al. 2008). Evidence from Cull et al., (2009) show that microfinance-aligned commercial banks issue out loans that are nearly four times as large as those issued by NGOs, substantiating mission drift. Essentially, deposits as much as they spur FS, MFIs must be equipped to deal with licensing costs which might curtail outreach depth.
3.4. Equity and FS. Sekabira, (2013) on capital structure and its role on the performance of microfinance in Uganda recommended the increased use of equity and discourage the dependence on grants and subsidies. Evidence as early as 1999 by Conning reveal that sustainable MFIs which are capable of serving the poor ought to be largely equity financed. Low costs associated with equity, given that dividend payment is not an obligation, boost FS (Tehulu, 2013). Further evidence by Hartaska \& Nadolnyak, (2007) approves equity in stimulating FS. However, equity remains a rare and scare resource in microfinance as put forward by MIX (2012), thereby requiring supplements of other funding options to meet demand.

Conversely, Kumar, (2012) suggests that FS can explain the level of equity assumed by MFIs. The franchise-value hypothesis state that MFIs which achieve FS normally have high equity levels, so as to guard against the loss of economic rents or value of the franchise from probable liquidation. If economic rents are expected to increase, and efficiency (FS) is expected to continue in perpetuity, shareholders are incentivized to hold more equity, hence, enjoy ultimate control of the rents. Empirical evidence shows that, banks hold on to additional equity to protect the value of their franchises (Berger \& di Patti, 2006). Further evidence also supports the notion that firms tend to be equity financed where such firms have inimitable products with the potential of creating market power rents (Titman \& Wessels, 1988). On the contrary, the efficiency-risk hypothesis explains low equity levels in an MFI. If chances of liquidation are low, MFIs are usually enticed to employ more debt, thus, cutting back on equity levels. Whereas there are MFIs which listed successfully on stock exchanges and raised enormous amounts of equity in Latin America (Cull et al., 2009), it still remains a nascent dream for most regions in the world to achieve the same development.

3.5. Generalized comment. The manner in which MFIs are financed varies with regions (see Figure 1.0 below).

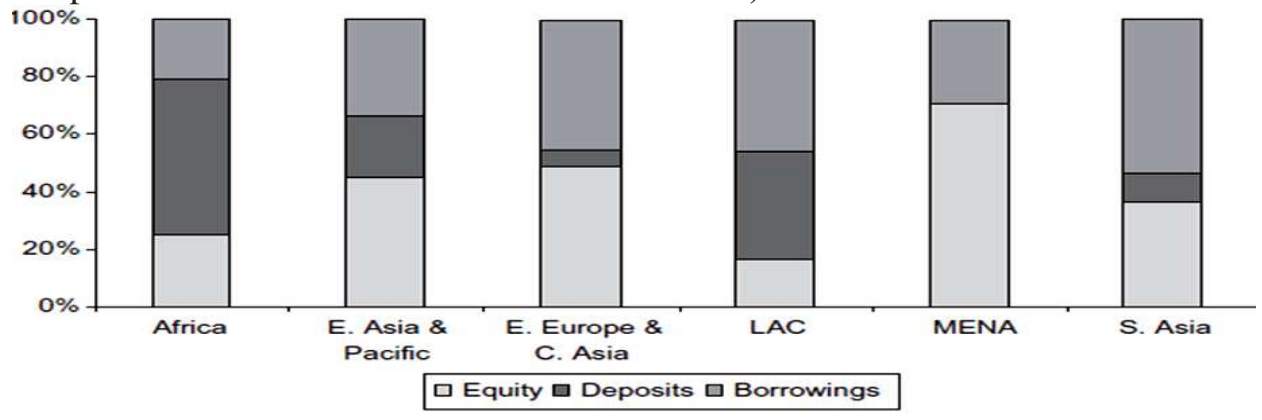

Source: Lafourcade et al. (2006).

Fig. 1. Global distribution of MFI funding sources 
African MFIs are mainly financed through deposits, whilst Middle East and North African (MENA) MFIs make use of equity. South Asian MFIs heavily depend on debt financing (MIX, 2013; Lafourcade et al., 2006). Therefore, the relationship between MFI financing options and FS would naturally vary with the region being considered. Variation in the effect of each financing option on FS is dependent on the study setup, i.e., the sample, the area considered, the period and level of financial development. This explains why Cull et al., (2009, p. 19) noted that "the exact nature of trade-offs in microfinance differ across regions, but meaningful trade-offs need to be recognized and weighed everywhere". Localized trends, thus, are instrumental in defining the nexus between financing and FS. This explains why no universal financing structure is identified in literature.

\section{Conclusion and recommendations}

The study sought to label the relationship between MFI financing and FS. Of note is that financing options for MFIs vary with regions. This can be explained by varying degrees of financial development and policies that govern the functioning of financial markets. Though subsidies are condemned for spurring distortions, inefficiency and harboring a dependency syndrome, subsidies are additive to FS though with a threshold limit. Smart subsidies are preferred to ensure maximum social impact is attained without prejudicing FS in the long run. Common ways of making subsidies "smart" include: "subsidizing the program, not the client", "strategic short-term subsidization of very poor clients", "strategic subsidization over the long term", as well as "crowding in other commercial financing options". However, effort has to be channeled towards proper measurement of efficiency and impact under subsidy financing for timeous withdrawal of subsidies to be made once operations attain FS.

The agency theory hails the role of debt in promoting FS, since it invokes cost efficiency. The pressure to attain enough revenue to service debt, cover operational costs and make profits propell MFIs towards FS. However, checks and balances have to be put in place to avoid excessive use of debt, as it may trigger bankruptcy, as well as sparking mission drift, as the need to cut administrative costs on small loans to maintain. Whilst savings are a stabilizer and endorse FS since they come at low cost, licensing costs might oppose FS in the short run. Getting licensed to attract savings requires the hiring of experts, conforming to set capital requirements and the upgrading of systems. This might curtail FS in the short run if MFIs are not prepared to meet such costs, hence, trigger mission drift as MFIs resort to bigger loans whose associated administration fees are low. We implore governments to make the attraction of deposits cheaper by reducing regulatory costs to MFIs. This will go a long way in supporting FS. Equity, though cheap, remains a scarce resource in microfinance as few MFIs are listed on stock exchanges. All the same, equity is compatible with FS and feeds into a salient outreach depth. We suggest that MFIs should consider commercial funding, whilst keeping a check on the downside of each commercial financing option to reach FS and multiply outreach.

\section{References}

1. Abdelkarim, N. (2002). The Long Term Financial Sustainability Of the Palestinian NGO Sector: an Assessment. The Welfare Association Consortium.

2. Amin, S., Rai, A.S. \& Topa, G. (2003). Does Microcredit reach the poor and vulnerable? Evidence from Northern Bangladesh, Journal fo Development Economics, 70 (1), pp 59-82.

3. Asian Developmwnt Bank. (2010). Finance fo the poor: Microfinance development stratedy. Asian Development Bank. Available at: http://www.adb.org/sites/default/files/institutional-document/32094/financepolicy.pdf.

4. Aveh, F.K., Krah, R.Y. \& Dadzie, P.S. (2013). An evaluation of sustainability and subsidy dependency of MFIs in Ghana, International Business and Management, 6 (1), pp. 55-63.

5. Ayayi, A.G. \& Sene, M. (2010). What drives microfinance Institution's financial sustainability, The Journal of Developing Areas, 44 (1), pp 303-324.

6. Berger, A.N. \& di Patti, B.E. (2006). Capital structure and firm performance: A new approach to testing agency theory and an application to the banking industry, Journal of Banking \& Finance, 30, pp. 1065-1102.

7. Bogan, L.V. (2012). Capital Structure and Sustainability: An Empirical Study of Microfinance Institutions, $A$ Review of Microfinance and Statistic, 94 (4), pp. 1045-1058.

8. Brau, J.C. \& Woller, G.M. (2004). Microfinance: A Comprehensive Review of Existing Literature, Journal of Entrepreneural Finance and Finance Ventures, 9 (1), pp. 1-26. Buss, F.T. (1999). Microenterprise in International Perspective: An overview of issues, International Journal of Economic Development, 1 (1), pp. 1-28. Available at: http://www.spaef.com/file.php?id=1007.

9. CGAP. (2004). Foreign Investment in Microfinance: Debt and Equity from Quasi-Commercial Investors. Washington D.C: CGAP.

10. CGAP. (2005). Maximising the Outreach of Microenterprise Finance: The Emerging Lessons of Successful Programs. CGAP Focus No. 2, Washington. 
11. Coleman, A.K. (2007). The Impact of Capital Structure on perfomance of microfinance institutions, Journal of Risk Finance, 8 (1), pp 56-71.

12. Conning, J. (1999). Outreach, sustainability and leverage in monitored and peer-monitored lending, Journal Development Economics, 66, pp. 51-77.

13. Cull, R., Demirgüç-Kunt, A. \& Morduch, J. (2009). Microfinance Meets the Market, Journal of Economic Perspectives, 23 (1), pp.167-192. Available at: http://dx.doi.org/10.1596/1813-9450-4630.

14. Cull, R., Demirguc-Kunt, A. \& Morduch, J. (2011). The effect of regulation on MFI profitability and outreach, World Development, 39 (6), pp. 949-965.

15. De Aghion, A.; Morduch, J. (2005). Microfinance - where do we stand? In Financial Development and Economic Growth: Goodhart, C, (ed.). Palgrave.

16. De Sousa-Shields, M. \& Frankiewicz, C. (2004). Financing Microfinance Institutions: The Contexts for Transition to Private Capital:Accelerated Microfinance Advancement Project. USAID, Washington D.C.

17. Duflows, E., Luchtenburg, P., Ren, L. \& Chen, L.Y. (2013). Microfinance in Myannar: Sector assessment. IFC Advisory Services in East Asia and the Pacific.

18. Faulkender, M. \& Peterson, M.A. (2004). Does Source of Capital Affect Capital Structure? Review of Finance Studies, 19 (1), pp. 45-79.

19. Fehr, D. \& Hishiguren, G. (2006). Raising capital for microfinance: Sources of funding and opportunities for equity financing, Journal of Development Entreprenuership, 11, pp. 133-143. Available at: http://academicarchive.snhu.edu/bitstream/handle/10474/1657/cfs2004-01.pdf?sequence=1.

20. Forkusam, A.N. (2014). Does financial globalization affect microfinance mission drift in Microfinance Institutions: Financial and Social Perfomance. eds Mersland R. and Strom O, Palgrave Macmillan, UK.

21. Guntz, S. (2011). Sustainability and profitability of microfinance. Master's thesis, Georg Simon Ohm University of Applied Sciences Nuremburg.

22. Hallway, R., Hoque, M. \& Chisty, M. (2011). Commercialisation and Changes in Capital Structure in Microfinance Institutions: An Innovation or a Wrong Turn? Managerial Finance, 37 (5), pp. 414-425.

23. Hartaska, V. \& Nadolnyak, D. (2007) Do regulated microfinance institutions achieve better sustainability and outreach? Cross country evidence, Applied Economics, 39 (10), pp. 1207-1222.

24. Hermes, N. \& Lensick, R. (2007). The empirics of microfiance: What do we know? The Economic Journal, 117 (1), pp. F1-F10.

25. Hermes, N. \& Lensick, R. (2011). Microfinance: Its Impact, Outreach, and Sustainability, World Development, 39 (6), pp. 875-881.

26. Hoque, M. \& Chisty, M. (2011). Commercialization and Changes in Capital Structure in Microfinance Institutions. An Innovation or a wrong turn? Managerial Finance, 37 (5), pp. 414-425.

27. Hudom, M. \& Traca, D. (2011). On the efficiency effects of subsidies in microfinance: An empirical inquiry, World Development, 39 (6), pp. 966-973.

28. Iezza, P. \& La Cour, L. (2010). Financial sustainability of microfinance. Copenhagen: Copenhagen Business School.

29. IFC. (2010). Scaling-up SME access to financial services in the developing world. G20 Seoul Summit.

30. Isern, J. \& Porteous, D. (2005). Commercial Banks and Microfinance: Evolving Models of Success. CGAP Focus Note, June, pp. 1-8.

31. Jaramillo, M. (2013). ELLA Policy Brief: Latin American Innovation in Microfinance Technology. ELLA, Practical Action Consulting, Lima, Peru.

32. Kapper, A. (2007). Commercialisation of microfinance institutions. Paris Graduate School of Business, Paris.

33. Karim, S., Hanouch, M., Ketley, R. \& Sibanda, X. (2011). SADC Microfinance Study: Landscape, regulatory environment, level of monitoring and support. Johannesburg, South Africa.

34. Khandker, R.S. (1996). Grameen Bank: Impact, Costs, and Program Sustainability, Asian Development Review, 14 (1), pp. 65-85.

35. Khawari, A. (2004). Microfinance: Does it hold its promises? A survey of recent literature. Hamburg Institute of International Economics: HWWA DISCUSSION PAPER 276.

36. Kiiru, M.J. (2008). The effect of financing structure on the financial perfomance of deposit taking microfinance institutions in Kenya. Master's Thesis, University of Nairobi.

37. Kinde, B.A. (2012). Financial sustainability of microfinance institutions (MFIs) in Ethiopia, European Journal of Business and Management, 4 (15), pp. 1-11. Available at: http://pakacademicsearch.com/pdffiles/ech/517/110\%20Vol\%204,\%20No\%2015\%20(2012).pdf.

38. Kumar, K.A. (2012). Does capital and financing structure have any relevance in the perfomance of microfinance institutions? International Review of Applied Economics, 26 (3), pp. 329-348.

39. Kyereboah-Coleman, A. (2007). The impact of capital structure on the perfomance of microfinanceinstitutions, The Journal of Risk Finance, 8 (1), pp 56-71.

40. Lafourcade, A. et al. (2006). Overview of the Outreach and Financial Performance of Microfinance Institutions in Africa, Microbanking Bulletin, (April), pp. 3-14. Available at: http://www.themix.org/sites/default/files/MBB12OutreachandFinancialPerformanceofAfrican MFIs.pdf.

41. Local Government Association of Australia. (2015). Financial Sustainability Information Paper 1, Revised February 2015. The Voice of Local Government. 
42. Louis, P. \& Bart, B. (2013). Do for profit microfinance institutions achieve better financial efficiency and social impact? A generalised extimation equations panel data approach. Draft presented on Financial Globalisation and Sustainable Finance Conference: Implications for Policy and Practice, May 29-31, Cape Town.

43. Margaritis, D. \& Psillak, M. (2009). Capital Structure, equity ownership and firm perfomance, Journal of Banking and Finance, 34, pp. 621-632.

44. Mersland, R. \& Strom, R.O. (2010). Microfinance and Mission Drift, World Development, 38 (1), pp. 28-36.

45. Mersland, R. \& Strom, R.O. (2012). The past and future of innovations in microfinance. The Oxford handbook of entrepreneurial finance, pp. 859-891.

46. Microfinance Information Exchange. (2013). Sub-Saharan Africa Regional Snapshot, MIX.

47. Modurch, J. (1999). The Microfinance Promise, Journal of Economic Literature, 37, pp. 1569-1614.

48. Morduch, J. \& Haley, B. (2002). Analysis of the Effects of Microfinance on Poverty Reduction. NYU Wagner Working Paper Series, Washington D.C.

49. Morduch, J. (2005). Smart Subsidies for Sustainable Microfinance: Finance for the poor, Quarterly Newsletter of the Focal Point of Microfinance, 6, pp. 1-7.

50. Morduch, J. (2000). The microfinance schism, World Development, 38, pp. 617-629.

51. Nyamsogoro, G.D. (2010). Financial sustainability of rural microfinance institutions in Tanzania. PhD Thesis: University of Greenwich, Australia.

52. Paul, M.S. (2010). Bridging the Gap to the Microfinance Promise: A Proposal for a Tax-Exempt Microfinance Hybrid Entity, International Law and Politics, 42, pp. 1383-1426. Available at: http://nyujilp.org/wpcontent/uploads/2010/10/nyi409-paul1.pdf.

53. Quayes, S. (2012). Depth of outreach and sustanability of microfinance institutions, Applied Economics, Vol 44, pp. 3421-3433.

54. Rhyne, E. (1998). The Yin and Yang of Microfinance; Reaching the poor and sustainability, Microfinance Bulletin, July Issue.

55. Robinson, M. (2001). The Microfinance Revolution: Sustainable finance for the poor. The World Bank, Washington.

56. Rosenburg, R. (2009). Measuring results of microfinance institutions: Minimum indicators donors and investors should track. CGAP Technical Guide, Washington, USA.

57. Roy, A. (2010). Poverty capital: Microfinance and the making of development. New York: Routledge.

58. Sekabira, H. (2013). Capital Structure and its role on perfomance of microfinance institutions: The Ugandan Case, Sustainable Agriculture Research, 2 (3), pp. 86-100.

59. Sontig-Pedilla, L., M., Staplefoote, L. \& Gonzalez Morganti. (2012). Financial Sustainability of Nonprofit Microfinance Institutions: Review of Literature. The Rand Corporation. Available at: http://www.rand.org/content/dam/rand/pubs/research_reports/RR100/RR121/RAND_RR121.pdf.

60. Tilahun, A.T. (2013) Determinants of Financial Sustainability of Microfinance Institutions in East Africa, European Journal of Business and Management, 5 (17), pp. 152-159.

61. Tehulu, T.A. (2013) Determinants of financial sustainability of microfinance institutions in East Africa, European Journal of Business and Manegement, Vol. 5, No. 17, pp. 152-158.

62. Titman, S. \& Wessels, R. (1988). The determinants of capital structure choice, Journal of Finance, 43, pp. 1-19.

63. Vacklen, S. (2010). Blended Value Investment and the lessons learned from development studies. Master's Thesis, Lund University.

64. Von Pischke, J.D. (1996). Measuring the trade-off between outreach and sustainability of microenterprise lenders, Journal of International Development, 8 (2), pp. 225-239.

65. World Economic Forum. (2010). Rethinking Financial Innovation: Reducing negative outcomes while retaining the benefits. World Economic Forum, Geneva.

66. Zviniene, Asta, Whitehouse, Edward. (2010). Financial sustainability. Assessing the finances of pension systems over the long term. World Bank pension indicators and database briefing; no. 6. Washington, DC: World Bank. 